\title{
Diagnosis of Dieback Disease of the Nutmeg Tree in Aceh Selatan, Indonesia
}

\section{Susanna SUSANNA ${ }^{1, *}$, Meity Suradji SINAGA ${ }^{2}$, Suryo WIYONO ${ }^{2}$ and Hermanu TRIWIDODO ${ }^{2}$}

\author{
${ }^{1}$ Studi Program of Plant Protection, Faculty of Agriculture, Syiah Kuala University, Aceh, Indonesia \\ ${ }^{2}$ Department of Plant Protection, Faculty of Agriculture, Bogor Agricultural University, Indonesia
}

('Corresponding author's e-mail: susanmulizar@gmail.com)

Received: 7 September 2017, Revised: 21 December 2018, Accepted: 20 January 2019

\begin{abstract}
Effective control disease measures require a great deal of knowledge about the pathogen, which is also applied to dieback disease of the nutmeg tree in Aceh Selatan District, Province of Aceh, Indonesia. The objectives of this study were to identify the causal agent of dieback disease on a nutmeg plantation and to assess the effect of drought stress on the development of dieback disease. Pathogen identification was carried out by observing the symptoms of infected plants, morphological characters of the isolated pathogens, Koch's postulates, and molecular analysis and pure pathogen cultures. The samples were taken from an infected part of the nutmeg plant (twigs, stems, and roots) in 6 subdistricts at the center of the nutmeg plantation in Aceh Selatan. Koch's postulates were performed by using the mycelia of pathogens on 1-year-old nutmeg seedlings. Drought stress was simulated everyday, and then once every 2 weeks, to study the effect of drought stress on dieback. The results showed that there were 4 genera of fungal pathogens (Botryodiplodia theobromae, Fusarium solani, Graphium euwallaceae, and Rigidoporus microporus) out of 6 fungi associated with dieback disease. However, B. theobromae Pat. turned out to be the dominant fungi associated with dieback on the nutmeg tree in Aceh Selatan. Drought stress was proven to be a predisposing factor for explaining this problem epidemic in Aceh Selatan.
\end{abstract}

Keywords: Drought stress, Koch's postulates, Pathogen, Botryodiplodia theobromae

\section{Introduction}

Nutmeg (Myristica fragrans) is an important plantation commodity for increasing Indonesia's foreign exchange and the livelihood of Indonesian society in general. As the world's largest nutmeg supplier, Indonesia contributes $70-75 \%$, while the remaining $20 \%$ comes from Grenada and $5 \%$ from Sri Lanka, Trinidad and Tobago. The most significant users of nutmeg products are the United States, Britain, and Germany [1].

Aceh Selatan District is 1 of the centers of nutmeg production in Indonesia. The nutmeg production of this region contributes greatly to the fulfillment of domestic and foreign nutmeg needs. The area of nutmeg plantations in Aceh Selatan District in 1994 reached 11,245 ha, with an average productivity of whole nutmeg of 8.2 tons/ha. In 2003, the total area had decreased to 9,843 ha, and the average total productivity decreased to 1.1 tons/ha. In 2014, the average value of Aceh nutmeg productivity had decreased to 0.7 tons/ha [2].

One of the factors that cause the declining productivity of nutmeg plants in Aceh Selatan is the socalled 'die-back' disease. Cases of this disease continue to spread throughout the nutmeg production centers in Aceh Selatan district. This has led to a production decline up to $70 \%$ [3]. Until 2016, the cause of the disease was not known for certain. Symptoms of die-back disease appear as necrosis of leaves, 
http://wjst.wu.ac.th

stems, branches, and twigs in the form of die-back that occur gradually and eventually result in complete die-back. Pathogens can attack and cause death in Nutmeg plants from the nursery stage, young plants that are not yet or already in production, or old ones [4-6].

The development of this disease may have been affected by prolonged drought impacts in Indonesia's land areas and, at the same time, changes in the ratio between the length of the dry and rainy seasons. This phenomenon has a negative impact on the agricultural sector, especially in terms of setting the planting time, and also causing an explosion in pest and plant diseases. The district of Aceh Selatan is located in the West/South coast area, which is predicted to be affected by drought caused by the dipole mode phenomenon [7]. In some cases, drought conditions will have an impact on the disease by making the environment more or less favorable for infection, disease progression, or disease spread. On the other hand, drought exacerbates the damage caused by disease in drought-affected plants.

Knowledge of the cause of the disease and the trigger factor of its development is needed to develop its control strategy. An understanding of the pathogens, as well as the factors driving the occurrence of the epidemic, is not yet complete. Therefore, a research program has been conducted to identify the cause of the disease and to find out the effect of drought stress on die-back disease on the nutmeg tree in Aceh Selatan.

\section{Materials and methods}

Research was conducted at Plant Mycology Laboratory, Department of Plant Protection, Bogor Agricultural University, and Laboratorium of Forestry Protection, Center for Forestry Research and Development, Bogor and its Experimental Station in Cimanggis, Bogor, from September 2015 September 2016.

\section{Disease diagnosis and identification of disease cause}

Infected nutmeg plant samples were taken from 36 nutmeg plantations in 6 sub-districts (Labuhan Haji Timur, Meukek, Sawang, Samadua, Tapaktuan, and Pasie Raja) in Aceh Selatan. Infected plant tissues (stems, twigs, and roots) showing symptoms of die-back, leaf yellowing, and necrosis were surface sterilized, isolated, and incubated on PDA media for 3 days at room temperature. The pathogen was isolated and purified on the PDA to perform Koch's postulates. Koch's postulates were also performed on year-old Myristica fragrans nutmeg seedlings. Inoculation was achieved by attaching cultures to stems or roots that had been wounded and then wrapped with sterile cotton. Each treatment used 5 nutmeg seedlings. Observations were made daily on the development of symptoms in seedlings.

Identification of pathogen morphology refers to Street [8]; Leslie and Summerrel [9]; and Watanabe [10]. Molecular identification refers to Sambrook and Russell [11]. The amplification product produced was sent to Bioneer (Korea) to sequence the nucleotides. The DNA sequence was analysed using BLAST and was compared with the NCBI Gen Bank data.

\section{Drought relation with disease occurrence}

The association of drought with disease occurrence was analyzed based on rainfall data in Aceh Selatan during the last 15 years. Climate data was obtained from local BMKG and disease data for 6 years was obtained from the Plantation General Directorate. Simulation of artificial drought stress was achieved in the laboratory by watering once every 2 weeks, compared with daily watering. Artificial inoculation used pathogens detected in previous studies on 1-year-old plant seedlings. Observations were made daily; the observed variables were the latent period and the development of symptoms on nutmeg seedlings. The water content of the soil was also measured during the treatment. 


\section{Results and discussion}

Infected nutmeg plants in the field usually showed initial symptoms of dieback, i.e., dried and withered leaves on some twigs, which then spread from 1 branch to another until the whole part of the plant is affected. The leaves became brownish, curling, and hanging, and eventually fell. However, there were plants that wilted as a whole, showing yellowing, drying, falling leaves and, ultimately, complete death.

Based on field observations on nutmeg plants, it is known that every symptom that occurs in infected plants is clearly associated with die-back, either positively or negatively. Symptoms of die-back are clearly associated with leaf discoloration, cancer, borers, and fungal rhizomorphs. The associated symptoms are clearly exclusive, thus, if one symptom occurs, the other symptoms are absent; for example if one of these plants show wilting symptoms, it does not show other symptoms of dieback, such as leaves hanging, cancer, stem borers, or leaf loss (Table 1).

Table 1 Association of disease signs and symptoms on the nutmeg trees in Aceh Selatan.

\begin{tabular}{ccccccccc}
\hline $\begin{array}{c}\text { Symptoms } \\
\text { of the } \\
\text { disease }\end{array}$ & W & D & LH & D & C & SB & R & DL \\
\hline W & 1.000 & & & & & & & \\
D & $-0.173^{* *}$ & 1.000 & & & & & & \\
LH & $-0.222^{* *}$ & $0.717^{* *}$ & 1.000 & & & & & \\
D & $0.309^{* *}$ & $0.394^{* *}$ & $0.550^{* *}$ & 1.000 & & & & \\
C & $-0.320^{* *}$ & $0.350^{* *}$ & $0.581^{* *}$ & $0.719^{* *}$ & 1.000 & & & \\
SB & $-0.183^{* *}$ & $0.401^{* *}$ & $0.608^{* *}$ & $0.797^{* *}$ & $0.893^{* *}$ & 1.000 & & \\
R & -0.094 & -0.089 & $-0.142^{* *}$ & $0.214^{* *}$ & $0.247^{* *}$ & $0.242^{* *}$ & 1.000 & \\
DL & $-0.149^{* *}$ & $-0.199^{* *}$ & $-0.289^{* *}$ & $0.376^{* *}$ & $0.491^{* *}$ & $0.469^{* *}$ & $0.549^{* *}$ & 1.000 \\
\hline
\end{tabular}

** = Association very significant, Wilt (W), Dieback (D), Leaves hanging (LH), Discoloration (D), Cancer (C), Stem Borer (SB), Rizomorph (R), Dieback and Leaf loss (DL); $n=360$ trees

\section{Koch's Postulates, Morphological and Molecular Identification of Pathogens}

Based on the Koch's Postulates test, it was observed that there were 4 types of fungus that showed the same symptoms, ranging from the formation of cancer in the seeds of inoculated plants, dead shoots/twigs, hanging leaves until dieback and, when the stems were cut transversely or slashed, necrosis seen in its vessels (Figure 1). The test results prove that the fungi A, B, C, and D are disease-causing fungi (Table 2). 


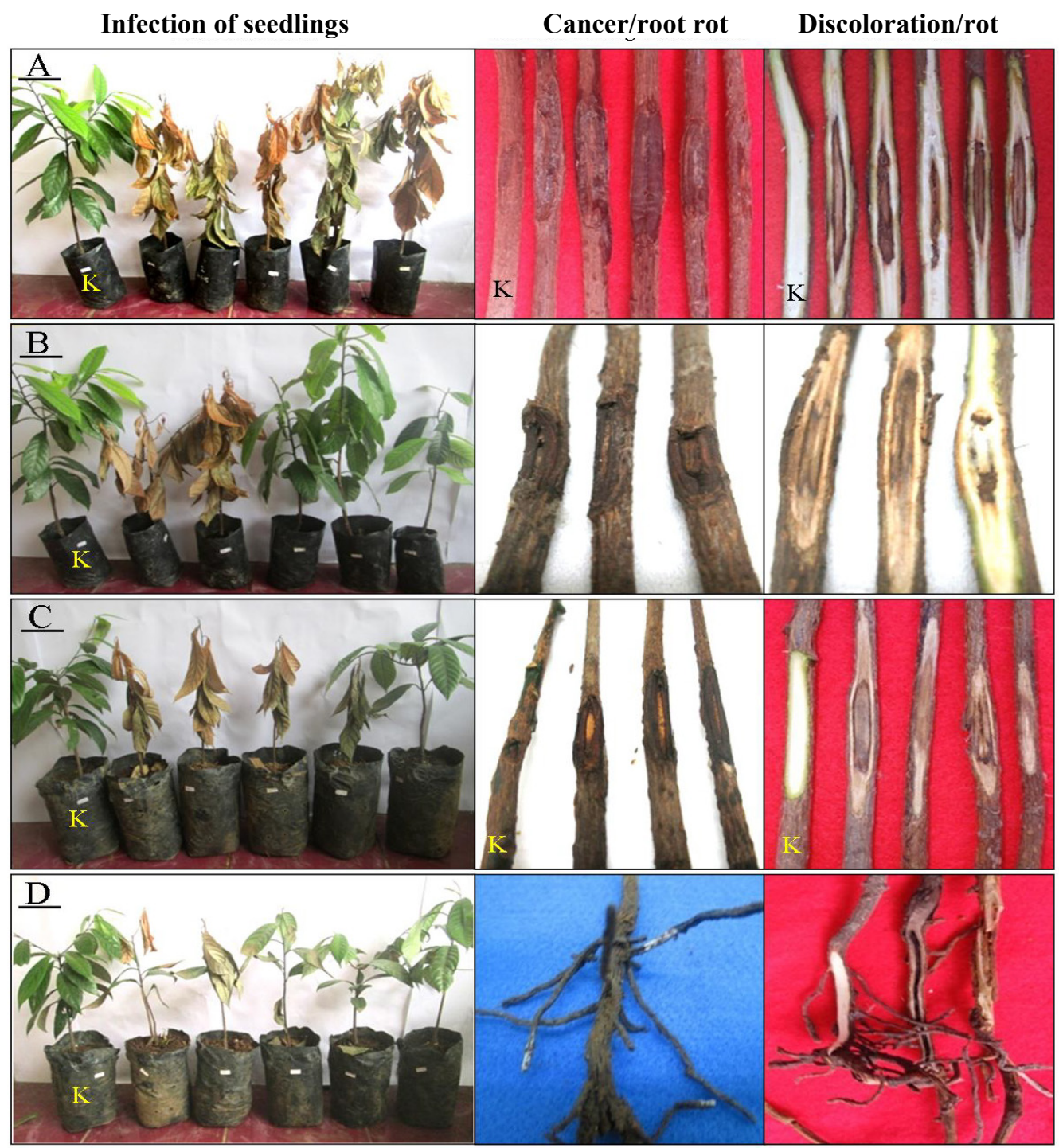

Figure 1 Results of artificial inoculation of the nutmeg seedlings; inoculation of Botryodiplodia sp. (A); inoculation of Graphium sp. (B); inoculation of Fusarium solani (C); inoculation of Rigidoporus sp. (D); without pathogens $(\mathrm{K})$.

The initial symptom of artificial inoculation was cancer, with an average incubation period of 32 days. The symptoms formed were initially not developed but, after the seeds received drought treatment, a month later, symptoms of died shoots and twigs began to appear and then spread to all parts of the plant, continued with drying leaves, which were left hanging for 4 to 8 weeks, then died, and the plant suffered full dieback. The seeds of nutmeg plants inoculated with isolates of fungus D did not show symptoms of cancer, but displayed root rot symptoms, because the pathogen was a fungus isolated from the root parts of the nutmeg plant, showing the fungal hyphae (rhizomorph) that wrapped around the root parts of the plant, but the symptoms formed on the upper parts of the plant, showing similar symptoms to those caused by other fungus tests. 
http://wjst.wu.ac.th

Table 2 Symptoms of an isolated fungus.

\begin{tabular}{|c|c|c|c|c|c|c|}
\hline \multirow[b]{2}{*}{ No. } & \multirow{2}{*}{$\begin{array}{l}\text { Fungus } \\
\text { isolates }\end{array}$} & \multirow{2}{*}{$\begin{array}{c}\text { Result of Koch's } \\
\text { Postulates }\end{array}$} & \multirow[b]{2}{*}{ Result of identification } & \multicolumn{3}{|c|}{ Frequency of isolates } \\
\hline & & & & $\begin{array}{l}\text { Stem } \\
(36)^{*}\end{array}$ & $\begin{array}{l}\text { Twig } \\
(36)^{*}\end{array}$ & $\begin{array}{l}\text { Root } \\
(36) *\end{array}$ \\
\hline 1 & $\mathrm{~A}$ & + & Botryodilodia sp. & 36 & 36 & 36 \\
\hline 2 & $\mathrm{~B}$ & + & Graphium sp. & 4 & 4 & - \\
\hline 3 & $\mathrm{C}$ & + & Fusarium solani & 2 & 2 & 5 \\
\hline 4 & $\mathrm{D}$ & + & Rigidoporus sp. & - & - & 2 \\
\hline 5 & $\mathrm{E}$ & - & Endomelanconiopsis sp. & 1 & - & - \\
\hline 6 & $\mathrm{~F}$ & - & Clonotachys sp. & 2 & - & - \\
\hline
\end{tabular}

Description: $+=$ exists (positive at all stages of Koch's postulates); - = none; $*=$ The numbers in brackets indicate the total number of samples.

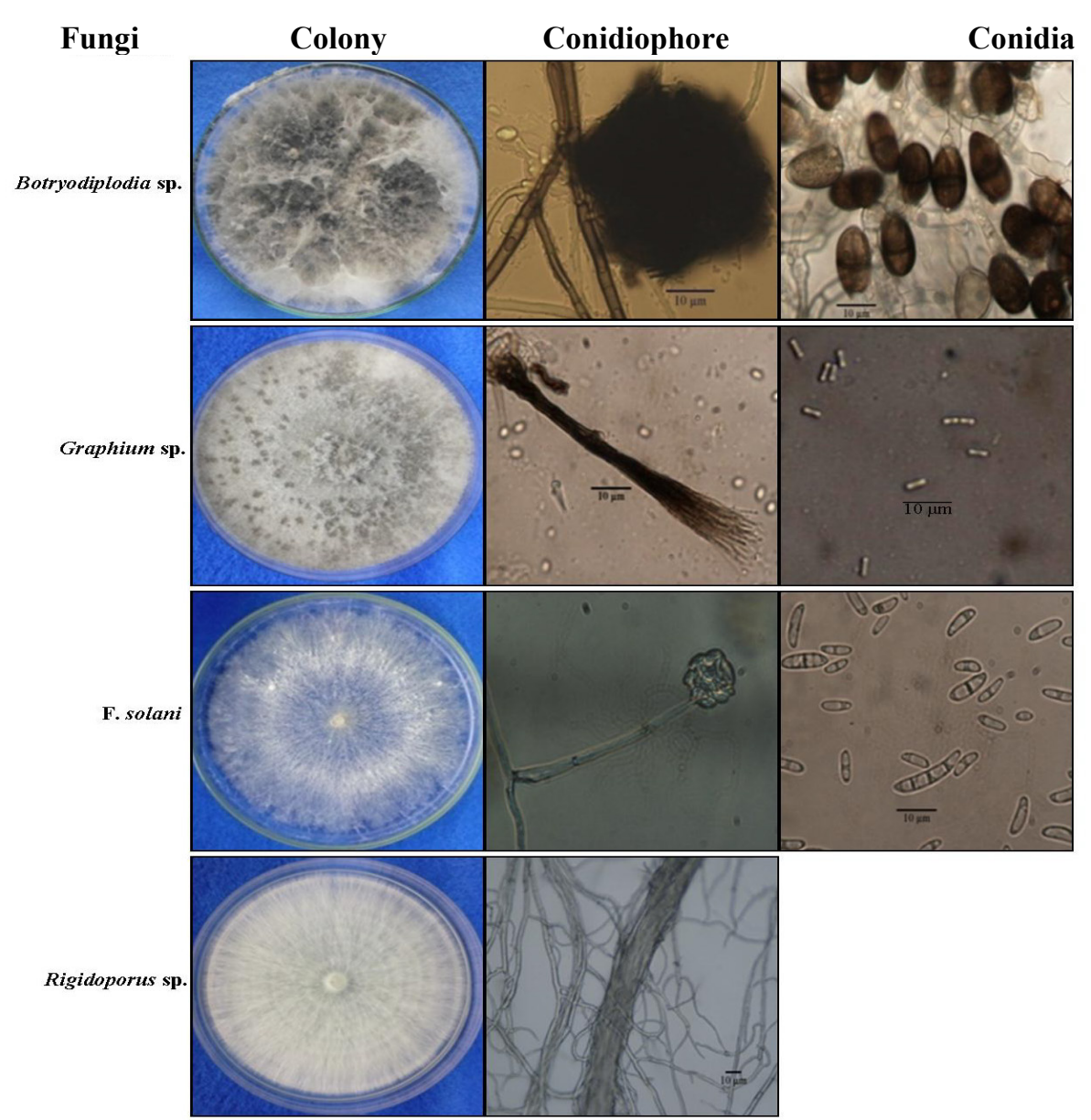

Figure 2 Morphology of colonies on PDA medium and microscopic structure of pathogenic fungi from nutmeg. 
http://wjst.wu.ac.th

The frequency of the fungus when isolated from stricken plant tissue from 36 sample sites was very variable. Botryodiplodia sp. was the most dominant type of fungus found; it could even be found by the direct spore trapping technique using MA and PDA media around the stricken plants. Four fungi (A, B, $\mathrm{C}$, and D) found in association with dieback plants gave positive results at all stages of Koch's postulates. This proves that all 4 fungi can cause die-back symptoms. After the re-isolation of the test plant, the 4 fungi showed similar results to the initially isolated pathogenic fungi (Table 2).

The isolated fungi were from 6 genera, but only 4 isolates were pathogenic. Isolate A was identified as Botryodiplodia sp., with white early colonies and very rapid growth of aerial mycelia, which then turned gray on the 4th day and turned black on the 7th day. Microscopically, the fungus has a hyaline, as initial hyphae that turns dark could form pycnidia within \pm 30 days after isolation by producing a not insulated young hyaline conidia that later showed a color change to brown, with partition in the center. Isolate B was identified as Graphium sp. with white early colonies turning gray, and after 7 days turning black. This fungus had a conidiophore bond forming synema and conidia produced in cylindrical form. Isolate $\mathrm{C}$ was identified as $F$. solani that formed a white colony with thin mycelium, had a long conidiophore which produced 2 types of conidia, i.e., microconidia with either a partition or not; and macroconidia with a partition between 2 and 4, hyaline chlamydospores that were formed on the intercalary or hyphae tip. Isolate D was identified as Rigidoporus sp. because it formed a thin white colony, with hyaline hyphae and branches, but did not have clam connection. The 4 isolates had characteristics corresponding to the genus on the identification keys used (Figure 2).

Furthermore, the molecular identification process was performed to confirm the morphologically identified fungal species. Visualization of PCR results showed that band amplification performed using primers ITS1 and ITS4 looked as expected. Amplification of DNA bands formed on agarose had a size of about $\sim 500-650$ bp (Figure 3). The size corresponded to a group of fungi.

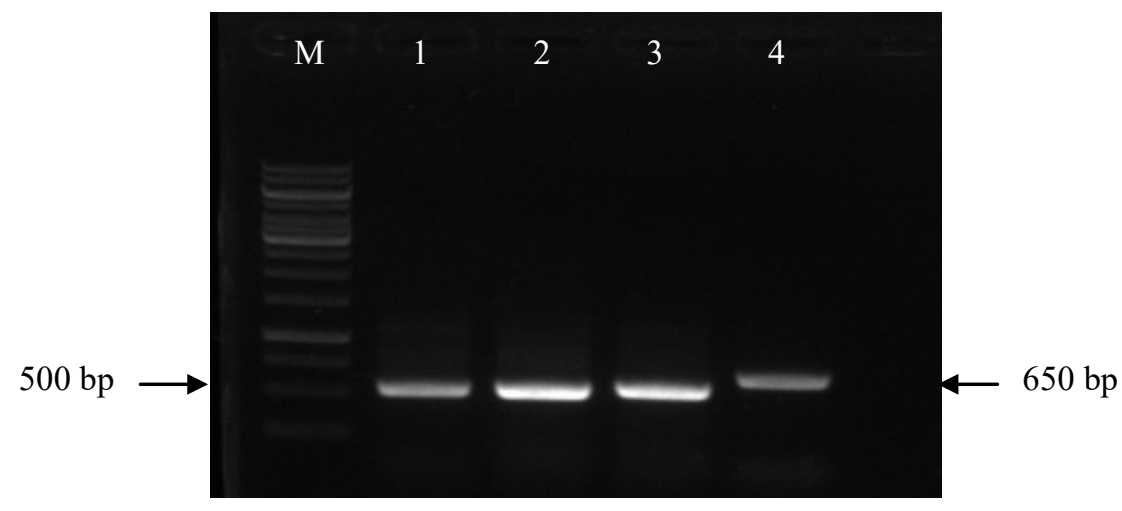

Figure 3 Electrophoresis visualization of PCR results of 4 fungi isolates using primary ITS1 and ITS4. $\mathrm{M}=$ Marker; 1. Botryodiplodia sp.; 2. Graphium sp.; 3. F. solani; and 4. Rigidoporus sp.

According to Toju et al. [12], ITS primers are suitable for identifying field samples from the Ascomycetes and Basidiomycetes fungi, based on DNA strands. However, the fungus of the Deuteromycetes group can also be detected with the ITS primers.

Pathogens A, B, C, and D, which were isolated from nutmeg samples, were identified as Botryodiplodia theobromae (syn. Lasiodiplodia theobromae), Graphium euwallaceae, Fusarium solani, and Rigidoporus microporus, with $100 \%$ query cover characterization, 99 - $100 \%$ identity and e-value 0.0 (Table 3). 
http://wjst.wu.ac.th

Table 3 Identification of pathogenic fungi based on ITS compared with NCBI GenBank data.

\begin{tabular}{lllcccc}
\hline \multicolumn{1}{c}{ Isolate } & \multicolumn{1}{c}{ Description } & No. Assesion & Strain & $\begin{array}{c}\text { Query cover } \\
(\mathbf{\%})\end{array}$ & $\begin{array}{c}\text { Identity } \\
(\mathbf{\%})\end{array}$ & E-value \\
\hline A (LH) & L. theobromae & KM278132.1 & NZD mf2 & 100 & 100 & 0.0 \\
B (MK) & G. euwallaceae & KF54022.1 & UCRFD97 & 100 & 100 & 0.0 \\
C (TT) & F. solani & KU377470.1 & C219 & 100 & 100 & 0.0 \\
D (PR) & R. microporus & KM246744.1 & RL & 100 & 99 & 0.0 \\
\hline
\end{tabular}

Description: - = is being re-sequenced

\section{The effect of drought stress on dieback and leaf loss}

What is important in understanding the epidemic of this disease is what triggers the epidemic. Climatic data over the past fifteen years indicates that rainfall in South Aceh district has declined by as much as $50.5 \%$ (Figure 4).

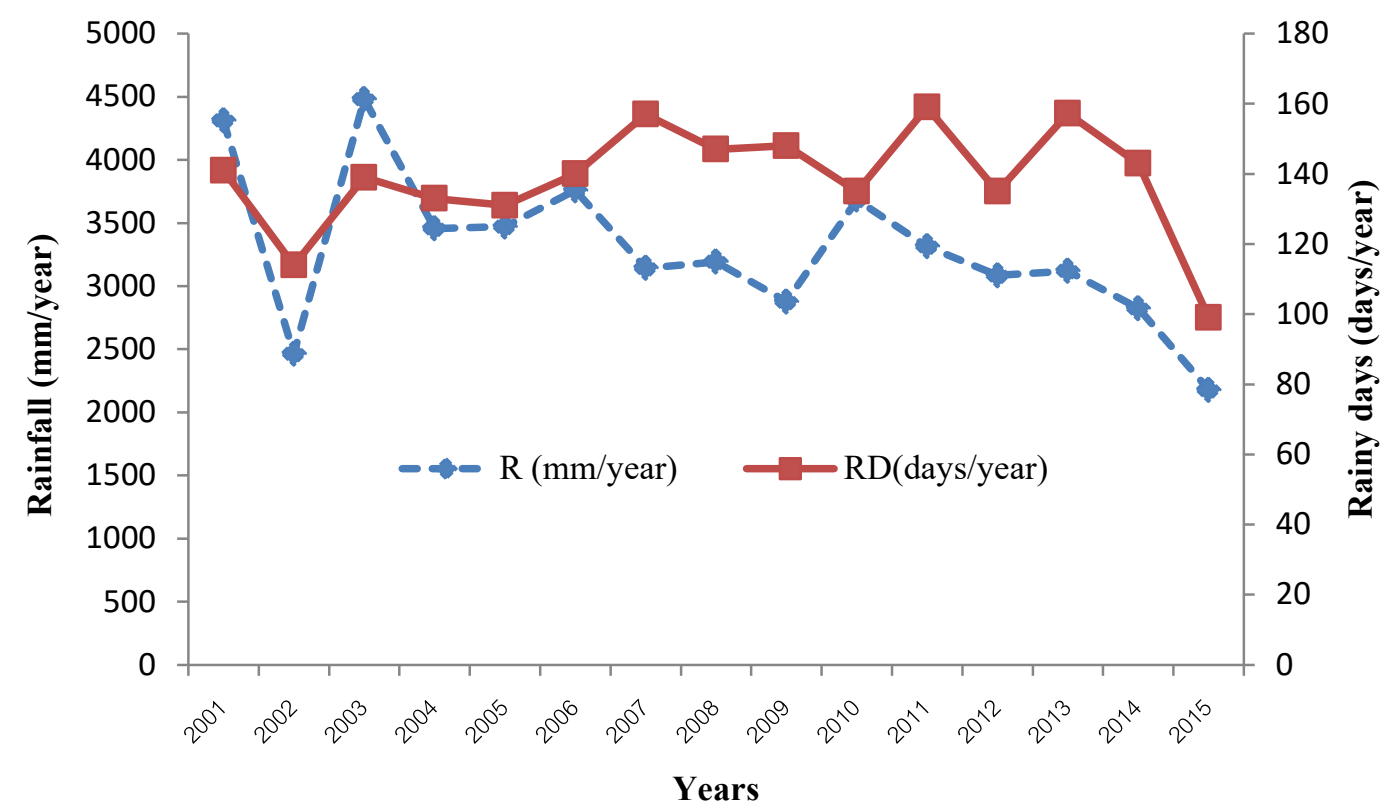

Figure 4 Graph of rainfall and number of rainy days for 15 years in Aceh Selatan District. 


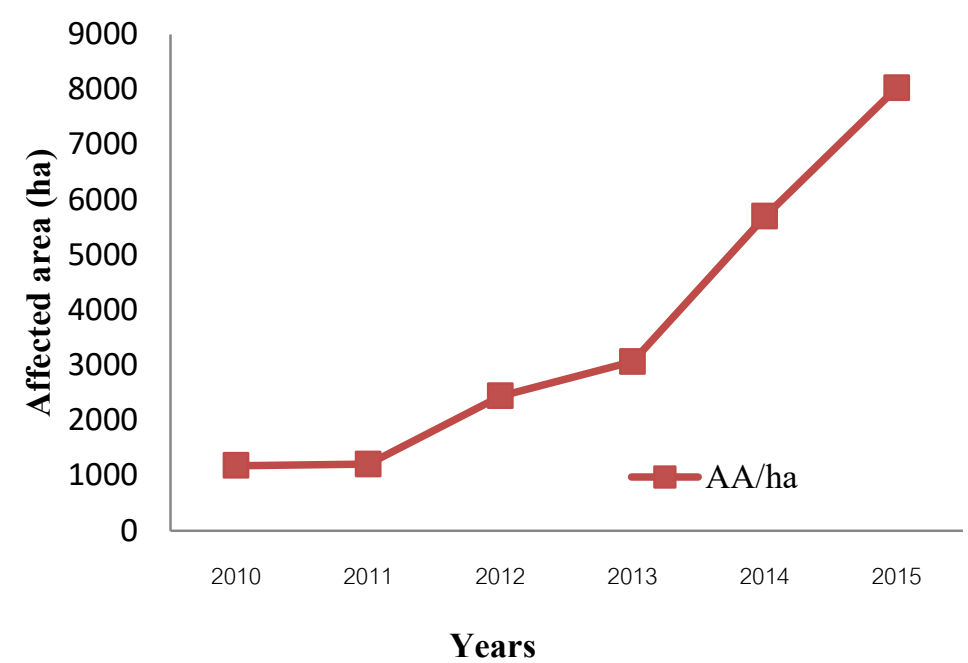

Figure 5 Graph of area of nutmeg plant that died over 6 years in Aceh Selatan District

Based on observations over the past 6 years, the area of nutmeg plants that have suffered dieback disease in Aceh Selatan has increased from 2010 to 2015 (Figure 5). As this is associated with the much reduced rainfall that has occurred in Aceh Selatan district, the increased incidence of the dieback disease in the field may be explained by the drought effect.

The impact of the drought phenomenon on nutmeg plants can be shown by providing very different watering treatments. Experiments with drought simulations indicated the differences on initial time of the emergence of each of the symptoms. Watering every 2 weeks (simulated drought conditions) showed symptoms that appeared more quickly and severely when compared with daily watering. In the daily watering scheme, only non-spreading cancer symptoms appeared. The incision on the stem showed that the xylem discoloration formed was more prominent in seedlings treated with drought stress, whereas in the nutmeg plant seedlings that were watered every day, the xylem discoloration was not well developed (Table 4 and Figure 6).

Table 4 Influence of watering on the development of die-back disease in nutmeg seedlings.

\begin{tabular}{|c|c|c|c|c|c|c|}
\hline Watering & Isolate & $\begin{array}{c}\text { The } \\
\text { beginning of } \\
\text { cancer (dai) }\end{array}$ & $\begin{array}{l}\text { The beginning } \\
\text { of dieback } \\
\text { (dai) }\end{array}$ & $\begin{array}{c}\text { Leaves hanging } \\
\text { (dai) }\end{array}$ & $\begin{array}{l}\text { Dieback and } \\
\text { leaf loss (dai) }\end{array}$ & $\begin{array}{c}\text { Length of } \\
\text { discoloration } \\
(\mathrm{cm})\end{array}$ \\
\hline \multirow{5}{*}{ Everyday } & Control & 0.00 & 0.00 & 0.00 & 0.00 & 0.00 \\
\hline & B. theobromae & 32.60 & - & - & - & 2.50 \\
\hline & Graphium sp. & 34.80 & - & - & - & 2.24 \\
\hline & F. solani & 35.00 & - & - & - & 2.64 \\
\hline & Rigidoporus $\mathrm{sp}$ & - & - & - & - & $\mathrm{x}$ \\
\hline \multirow{5}{*}{$\begin{array}{l}\text { Once every } \\
2 \text { weeks }\end{array}$} & Control & 0.00 & 0.00 & 0.00 & 0.00 & 0.00 \\
\hline & B. theobromae & 29.60 & 59.40 & 121.40 & 155.00 & 8.86 \\
\hline & Graphium sp. & 33.00 & $63.75(1 / 5)$ & $125.00(1 / 5)$ & $155.75(1 / 5)$ & 4.28 \\
\hline & F. solani & 33.00 & $63.30(1 / 5)$ & $127.00(1 / 5)$ & $159.00(1 / 5)$ & 2.80 \\
\hline & Rigidoporus sp & - & $66.00(1 / 5)$ & $125.00(1 / 5)$ & $157.00(1 / 5)$ & $\mathrm{x}$ \\
\hline
\end{tabular}

Description: - = Not showing symptoms until the end of observation; $\mathrm{x}=$ root rot; dai = days after inoculation

$808 \quad$ Walailak J Sci \& Tech 2020; 17(8)


http://wjst.wu.ac.th

The development of plant roots is generally influenced by the balance between water, air, and soil solidity. Good soil conditions support optimal growth of roots. A lack of water causes the soil structure to harden so that it inhibits the development and function of the roots in absorbing nutrients and water. This certainly has an impact on stunted plant growth and increased root exudation, resulting in weaker plants [13]. When plants have already been weakened by drought, the risk and impact of infection by pathogens will be even greater.

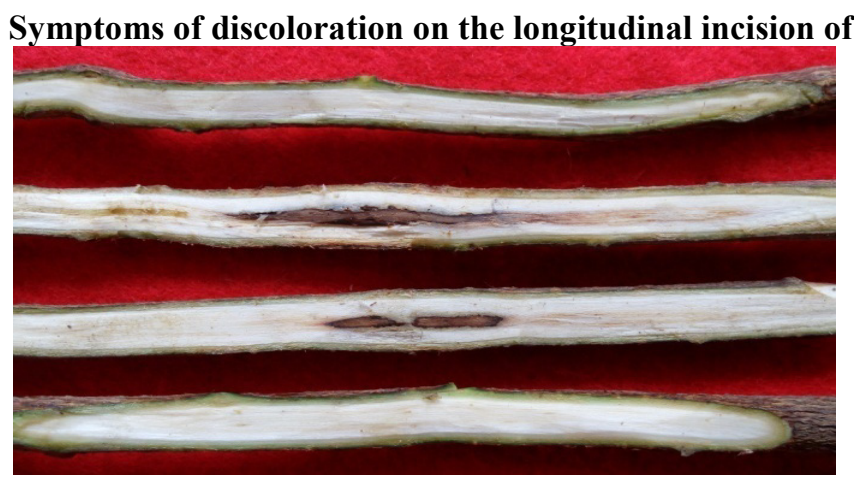

\section{Treatments}

Without pathogens on watering every 2 weeks

Watering every 2 weeks

Watering every day

Without pathogen on watering every day

Figure 6 Symptoms of discoloration due to the effects of drought stress.

Watering every 2 weeks, as a simulation of drought stress, induced very dry soil conditions at about $25 \%$ of field capacity. This condition caused the plant to be severely stressed and weakened. The district of Aceh Selatan has experienced a serious decline in rainfall over the last 15 years. This is likely to cause the plants to become stressed and, thus, more vulnerable to attack by pathogens. As a result, the occurrence of dieback disease has increased. For certain diseases, such as stem and root rot, the intensity of the attack is strongly influenced by the drought stress factor: the drier the condition is, the higher the disease's intensity $[6,14,15]$.

Drought affects the biochemical balance and concentration of many components in plant tissues, including nitrogen compounds, such as amino acids and nitrates; osmolites, such as sugars and inorganic ions; and chemical alleles, such as cyanogenic glycosides, terpenoids, and alkaloids. The increasing concentration of these compounds may result in inhibition of plant growth, photosynthesis, and nutrient uptake, so plants become more vulnerable to attack by pathogenic organisms. Additional important factors for determining disease severity under dry conditions are pathogen status, plant part, and water stress intensity $[6,16]$.

\section{Conclusions}

The cause of dieback disease in nutmeg trees in South Aceh is Botryodiplodia theobromae Pat. (syn. Lasiodiplodia theobromae (Patouillard) Griffon \& Maubland). The epidemic of the dieback disease began from 2003. The dramatic decline of rainfall over the last 15 years is a factor in triggering the dieback epidemic of nutmeg trees. The lower the rainfall is, the more likely it is the disease will happen.

\section{Acknowledgements}

The authors are grateful to the Ministry of Research, Technology and High Education, Indonesia, for their financial support to conduct this research work. 
http://wjst.wu.ac.th

\section{References}

[1] Direktorat Jenderal Perkebunan [Ditjenbun]. Statistik perkebunan Indonesia 2016. Jakarta (ID). Dirjenbun Indonesia, 2016.

[2] Dinas Kehutanan dan Perkebunan [Dishutbun]. Pedoman Pengamatan dan Pengendalian Hama pada Tanaman Pala. Tapaktuan, Aceh Selatan, 2014.

[3] EA Hadad and C Firman. Budidaya pala. Balittro, Bogor (ID), 2003.

[4] T Corcobado, E Cubera, E Juarez, G Moreno and A Solla. Drought events determine performance of ouercus ilex seedlings and increase their susceptibility to Phytophthora cinnamomi. Agri. For. Meteor. 2014; 1, 192-3.

[5] R Harni and IM dan Trisawa. Observasi dan identifikasi penyebab matinya pala di daerah Aceh Selatan. Laporan Kerjasama Dinas Kehutanan dan Perkebunan dengan Balai Penelitian Tanaman Rempah dan Aneka Tanaman Industri. Sukabumi, 2011.

[6] H Jactel, J Petit, ML Loustau, S Delzon, D Piou, A Battisti and J Koricheva. Drought effects on damage by forest insects and pathogens: A meta - analysis. Global Change Biol. 2012; 18, 267-76.

[7] Badan Meteorologi, Klimatologi, dan Geofisika [BMKG]. Informasi perubahan iklim. Stasiun Klimatologi Kelas IV Aceh Besar. Aceh (ID), 2017.

[8] RB Streets. The Diagnosis of Plant Diseases: A Field and Laboratory Manual Emphasizing the Most Practical Method for Rapid Identification. The University of Arizona Press Tuscon, Arizona. 1972.

[9] JS Leslie and BA Summerel. The Fusarium Laboratory Manual. $1^{\text {st }}$ ed. Blackwell Publishing. Iowa, 2006.

[10] T Watanabe. Pictorial Atlas of Soil and Seed Fungi: Morphologies of Cultured Fungi and Key to Species. Lewis Publishers, Tokyo, 1994.

[11] J Sambrook and DW Russel. Molecular Cloning a Laboratory Manual. $3^{\text {rd }}$ ed. Cold Spring Harbor Laboratory Pr., New York, 2001.

[12] H Toju, AS Tanabe, S Yamamoto and H Sato. High-coverage ITS primers for the DNA-based identification of ascomycetes and basidiomycetes in environmental samples. Plos One 2012; 7, 111.

[13] AP Whitmore and WR Whalley. Physical effects of soil drying on roots and crop growth. J. Exp. Bot. 2009; 60, 2845-57.

[14] TE Kolb, CJ Fettig, MP Ayres, BJ Bentz, JA Hicke, R Mathiasen, JE Stewart and AS Weed. Observed and anticipated impacts of drought on forest insects and disease in the United States. For. Ecol. Manag. 2016; 380, 321-34.

[15] RN Sturrock, SJ Frankel, AV Brown, PE Hennon, JT Kliejunas, KJ Lewis, JJ Worrall and AJ Woods. Climate change and forest diseases. Plant Pathol. 2011; 60, 133-49.

[16] J Lipiec, C Doussan, A Nosalewicz and K Kondracka. Effect of drought and heat stress on plant growth and yield: A review. Int. Agrophys. 2013; 27, 463-77. 